\title{
Leadership Styles and Teachers' Job Satisfaction in Tanzanian Public Secondary Schools
}

\author{
Fabian W. Nyenyembe ${ }^{1, *}$, Ralf Maslowski ${ }^{2}$, Beatrice S. Nimrod ${ }^{3}$, Levina Peter ${ }^{4}$ \\ ${ }^{1}$ Department of Education, Korogwe Teachers College, Tanzania \\ ${ }^{2}$ GION, University of Groningen, Netherlands \\ ${ }^{3}$ Department of Education, Korogwe Teachers College, Tanzania \\ ${ }^{4}$ Department of Education, The Mwalimu Nyerere Memorial Academy, Tanzania
}

Copyright $\bigcirc 2016$ by authors, all rights reserved. Authors agree that this article remains permanently open access under the terms of the Creative Commons Attribution License 4.0 International License

\begin{abstract}
This study explores the relationship between leadership styles applied by school heads and teachers' job satisfaction in Tanzanian secondary schools. Using a questionnaire, data in this study was collected from 180 teachers in ten secondary schools in Songea District in Tanzania. The most salient finding of this study revealed that teachers were more satisfied with their job when their school heads work closely with them by mentoring them as well as paying attention to their personal well-beings. This study challenges the relevance of transformational and transactional leadership in Tanzanian schools by suggesting that good leadership encompasses both 'transformational' and 'transactional' styles.
\end{abstract}

Keywords Leadership Styles, Job Satisfaction, Secondary Education, Tanzania

\section{Introduction}

Over the past decades, secondary education has grown rapidly in Tanzania [20]. In 2004 the Secondary Education Development Program (SEDP) was launched with the support of the World Bank [47], followed by the Secondary Education Development Program II in 2015. The second Secondary Education Development Program aimed at improving the quality of secondary education in Tanzania through upgrading the existed school infrastructures, providing adequate funding to secondary schools, enhance capacity building and technical assistance to implement reforms. The program further aimed at improving equitable provision of teachers and the quality of teaching in the core subjects [48]. This last objective concerned, among other things, the deployment of teachers to rural areas, as Tanzania suffers from an uneven teacher deployment both between and within districts. The experience in teaching profession seemed to indicate that dissatisfied teachers regularly refused to take up posts in rural areas, or otherwise they even opt to leave the teaching profession.

Teacher job satisfaction is often regarded as an important facet in the commitment of teachers towards their school productivity, [2]. However, Next to perceived social status, examination grades and individual characteristics of teachers; leadership style is among the major influences affecting teachers' job satisfaction [11]. Several studies of leadership styles and teachers' job satisfaction support an effect of leadership behaviours and leadership styles of principals on teachers' job satisfaction [41] [16] [14] [10] [18] [35] [ 13]. The findings in these studies indicated that primary school heads leadership styles in Tanzania affects several aspects of teachers' wellbeing- the finding that is closely related to the teacher's job satisfaction.

According to [35] there is a shift from command and managerial compliance styles that emphasize hierarchy and control, to more contingent and creative leadership styles. They argue that Tanzanian schools are in need of transformational leadership. Such a leadership style would lead to teachers who are satisfied and motivated to work effectively towards the goals of the school. Although they found support for a relationship between aspects of transformational leadership and teachers' job satisfaction, some transactional styles were also found to stimulate job satisfaction among teachers. This second [26] finding revealed that transformational leadership is positively related to contingent reward leadership, but negatively to laissez-faire leadership.

Based on these findings, the question was to what extents were these findings true as far as Tanzanian public secondary schools are concerned. Hence this study intends to test the relationship between leadership styles applied by Tanzanian heads of secondary schools and teachers' job satisfaction. Moreover, in a more general sense, the current study it aims to further explore the feasibility of transformational and transactional leadership styles for characterizing effective leadership styles in secondary schools. For that purpose, the relationship between transformational and transactional aspects is examined. 


\section{Conceptual Framework}

[45] Characterizes leadership as "the process or activity of influencing an individual or group in effort towards achieving a goal" (p. 4). On the other side, Smith highlights that leadership is always directed towards organizing and coordinating the work of teachers and other school personnel towards the objectives or goals of a school. Moreover, a clear goal orientation of leaders is also stressed by [37], who describes leadership as interpersonal patterns in which a leader tries to find followers' potential needs by gratifying the needs to influence the followers so that the goals of the organization can be reached. Owens acknowledges that reaching the school goals however is a cooperative endeavor, and that, leaders have to take account of the needs of teachers, and stimulate teachers according to their needs in order to achieve school objectives. Unlike [45] who conceives leadership mainly as influencing teachers, [37] argues that successful leadership is dependent on the degree to which leaders are able to address the concerns and possibilities of their teachers. [19], moreover, emphasizes the commonality of goals and shared efforts of school leaders and teachers. He further advocates the notion of servant leadership by arguing that leaders should primarily be driven by concerns and needs of teachers, and work for their benefits even when it is against leaders' own personal interests [29].

The conceptions above highlight that leadership is perceived as a task of coordinating and organizing people and processes towards the goals of the school organization, despite the fact that the nature of the coordination and organization may differ. Leaders, on one end of the continuum, may employ more directive and influencing roles, next to more stimulating and supportive roles of empowering teachers in the school on the other end. These different roles and perspectives are greatly reflected by the terms transactional and transformational leadership. [12] Proposed these two terms to characterize two different styles leaders may employ in interaction with their personnel.

Transformational leadership is distinct from transactional leadership with regard to the process by which leaders motivate teachers or how leaders appeal to teachers' values and emotions [32] [49]. Transactional leadership motivates teachers by appealing to their self-interest. It is based on a 'give-and-take' relationship, in which compliance of teachers is exchanged for expected reward. Teachers' expectations from this transaction are that they will be able to fulfill their self-interests, and that, it is the leader's role to ensure that their teachers' needs are satisfied [10]. [35] Argues that transactional leadership thus may result in an efficient and productive workplace, nevertheless, the impact of transactional leadership will be limited compared to a more transformational style of leadership.

Transformational leadership is directed towards stimulation of self-worth and self-esteem of teachers [42]. Through coaching and inspiring teachers leaders stimulate teachers to become engaged in and committed to the school organization see also [49]. Transformational leadership does not depart from the assumption that school leaders and teachers have different needs and interests, but that, both have the same vision and objectives they try to achieve. School leaders broaden and elevate the interests of teachers, generate teachers' awareness and acceptance of the school aims and thus motivates them to go beyond self-interest for the good of the group cf.[31] [22]. Transformational leadership thus, as [43] argues, bonds the school leader and teachers within a collaborative change process that contributes to the performance of the school.

According to [12], transformational and transactional leadership therefore are opposite ends of the leadership continuum see also [17]. Transformational leaders employ a style that differs from transactional leadership regarding underlying assumptions of motivation and interpersonal relationships in organizations. [3], in contrast, however argues that transactional and transformational leadership are not discerned in a fundamental, but rather in a qualitative way. Transactional leadership skills, they argue, are necessary skills for good leadership, but are not sufficient to motivate personnel in such a way that they will perform at their best. Based on several studies, [3] concludes that transformational leaders have equal, or even better transactional skills than non-transformational leaders. The best leaders, as [30] put it, are transformational and transactional: "transformational behaviors augment the effects of transactional behaviors" (p. 178).

Transformational leaders appear to create conditions that foster teachers' job satisfaction. [10] found that teachers who felt that their work gave them a sense of self-esteem and provided them with opportunities for self-development were also more satisfied with their job. The way teachers perceived their work were influenced by the leadership style of the principal at school. Transformational leaders more often stimulated the self-esteem of teachers, gave them a feeling of success and allowed them to participate in determining school practices, see also [44]. As such, they indirectly affected teachers' job satisfaction - next to a direct effect the principal's leadership style had on the job satisfaction of teachers.

A charismatic leader is a visionary leader who inspires team members by self-sacrifice to strongly hold core values that strengthen the team as a whole. This style of leadership is very motivating and performance-driven [36]. Team members can expect the charismatic leader to acknowledge their efforts as meaningful and link their success as valuable to the organization's mission [23].

Charisma can enhance personal-organizational values that fit among team members by helping everyone to acknowledge and link their personal values to the values of the organization. The leader will emphasize goals and values on behalf of the follower that are meaningful to the organization and empower the follower to aim higher and take greater initiative. This leader exercises extraordinary personality traits that motivate his or her teammates to 
envision leaders as powerful stakeholders that contribute greatly to the success of their organization [23].

Benard Bass and Brue Avolio (the leading transformational leadership researchers) claim that Charismatic leadership is rather a component of transformational leadership; thus they view transformational leadership as a broader construct than Charisma [9]

Laissez-faire leadership is a style that implies the "lack of leadership" or a "hands off" approach to influence [36]. The leader avoids active participation in the responsibility of setting goals, clarifying expectations, organizing priorities or becoming involved when leadership direction is needed [46]. The laissez-faire leader is extremely passive and inactive, resulting in the expectant self empowerment of the follower [21]. Frequent absence and the lack of involvement of critical decision-making are utilized as a method of driving the follower to self management [15].

On the other hand, foreign English teachers who classify their school director as a transactional or laissez-faire director express higher satisfaction towards their jobs in general but feel more dissatisfied with their salary.[15 ]

Studies on teachers' involvement in decision making at school provide support for an indirect effect of leadership style on job satisfaction see, [40] [24]. When teachers are more involved in decision- making processes they also tend to be more satisfied with their job. These schools are characterized by an open climate, in which principals are perceived as democratic managers who maintain open channels of communication with their staff. In contrast, when principals exhibit a harsh and authoritative style teachers are more often dissatisfied with their job. These findings reflect [39] observation that greater involvement of teachers in decision making, especially regarding school-wide issues, is related to higher job satisfaction.

In summary, various studies suggest that teachers' job satisfaction is enhanced by professional autonomy and participation in decision-making processes at school. Additionally, an open communication style by the head teacher and trusting relationships in school contribute to a teacher's satisfaction. These activities and structures reflect to a large extent a transformational leadership style of principals. For a transactional leadership style, findings from previous studies indicate that these in part may be inhibiting teachers' job satisfaction. Dissatisfied teachers, for instance, more often report that their leader grants them autonomy without paying attention to their quality of work, and only intervenes after problems have occurred. Other aspects of transactional leadership might nevertheless arouse job satisfaction among teachers. Principals who are directive towards their teachers, creating clear rules and procedures and rewarding teachers for accomplished goals, often create a satisfactory work environment for teachers. Nonetheless, the body of knowledge indicates that with regard to teachers' job satisfaction these more formal aspects of leadership are less influential than a more transformational leadership style. Based on these findings, this study sets out to test these assumptions by addressing the following research questions:
1) To what extent is teachers' job satisfaction in Tanzanian public secondary schools related to transactional and transformational leadership styles?

2) To what extent are transactional and transformational leadership styles related to each other, and which leadership style best predicts teachers' job satisfaction?

\section{Method}

\section{Sample}

The study was carried out in public secondary schools located in the-Songea district in the southern part of Tanzania. The participants of the study consisted of 180 teachers from 10 secondary schools, which were randomly selected from the eligible number of 23 secondary schools in Songea district. A school was considered eligible when the head of school had been appointed and practiced leadership roles at the school for at least one year. Moreover, the school needed to have at least 18 teachers who had been working with the head of the school for at least one year. The schools that met these criteria was determined by the district secondary educational officer. After the selection of the schools, eighteen teachers from each secondary school were randomly selected from a list of eligible teachers provided by the head of the school. The response gathered indicated that All 180 selected teachers participated in the study, corresponding to a response rate of $100 \%$.

The study further noted from the data collected that, The number of male teachers in the study (53\%) was slightly higher than the number of female teachers $(47 \%)$. This reflects more or less the general proportional distribution of male teachers versus female teachers in most secondary schools in Tanzania. It was further revealed that the age of most of the teachers who participated in the study was relatively low as almost half of the teachers were below the age of 30 years, and $36 \%$ were between the age of 30 to 39 years old. This relatively low age was also reflected in the teaching experience of teachers. The data collected indicated that nearly $96 \%$ of the teachers had been in the teaching profession for a period of less than 10 years. Moreover, the data collected further revealed that a vast majority of secondary school teachers in the study held Bachelor's degree $(56 \%)$. About $37 \%$ of the teachers were diploma in education holders, while only $7 \%$ were holders of Master's degree.

\section{Variables and Instruments}

\section{Dependent Variable: Teachers' Job Satisfaction}

Teachers' job satisfaction was assessed by asking teachers to rate their perceptions on a 30 -item job satisfaction scale. The scale of teachers' job satisfaction in this study was adopted from the "Elementary Teachers Perception of Job Satisfaction and Retention" questionnaire [38]. Based on this questionnaire, some changes were made to adapt the items to the relevance of job related behaviors found in Tanzanian school settings. Respondents were asked to indicate to as 
what extent they agreed with each statement using a five-point Likert scale ranging from 1 (strongly disagree) to 5 (strongly agree), with higher scores indicating higher levels of job satisfaction. In the present study, Cronbach's alpha was .86 for the job satisfaction scale. All questionnaires were close ended questions.

\section{Independent Variable: Leadership Styles}

For measuring leadership styles, [4] Multifactor Leadership Questionnaire (MLQ) was adapted, as has been used in various countries both in educational and non-educational settings see [5] [6] [7]. The MLQ consists of seven subscales. For this study the wording of the MLQ items was slightly adapted in order to better reflect the context of Tanzanian secondary schools. The English language was retained since English is used as medium of instruction in Tanzanian secondary education. The following scales for measuring leadership styles were used:

1) Charismatic leadership (16 items): This scale reflects to what degree the school leader creates an attractive school vision, elevates teachers' goals and inspires teachers with enthusiasm and optimism. Examples of items are "The head of school is respected by all teachers" and "The head of school encourages me to hope for a bright future in our teaching profession and life". Cronbach's alpha for this scale was .96.

2) Individualized consideration (7 items): This scale reflects to what degree the school leader pays attention to each individual teacher's needs for achievement and growth by acting as a mentor. Examples of items are "I get credit and praise from the head of the school for doing my work well" and "The head of school finds out what I want and she/she tries to help me get it". Cronbach's alpha for this scale was .87 .

3) Intellectual stimulation (3 items): This scale reflects to what degree the school leader stimulates teachers to be innovative and creative by questioning assumptions, reframing problems, and approaching old situations in new ways. Examples of items are "The head of school helps me to think and solve old problems in new and alternative ways" and "The head of school has provided me with new ways of looking at things which I did not understand before in my teaching job". Cronbach's alpha for this scale was .78 .

4) Contingency reward (7 items): This scale reflects to what degree the school leader sets goals, rewards teachers' performance, and obtains necessary resources. Examples of items are "The head of school tells me what I should do, if I want to be rewarded for my efforts" and "The head of school assures me I can get what I personally want in exchange for my efforts for doing school duties". Cronbach's alpha for this scale was .83 .

5) Active management by exception (4 items): This scale reflects to what degree the school leader closely monitors teachers' performance and keeps track of mistakes, and takes corrective action whenever failure is observed. Examples of items are "The head of school spends most of his time solving disputes, troubles and conflicts in the school" and "Most of the time the head of the school follows closely my mistakes". Cronbach's alpha for this scale was .66.

6) Passive management by exception (4 items): This scale reflects to what degree the school leader is not aware of problems until informed by others, and whether he fails to intervene until serious problems occur. Examples of items are "The head of school does not take action until a problem becomes serious" and "The head of school waits until things have gone wrong in the school before he takes action". Cronbach's alpha for this scale was .76.

7) Laissez-faire leadership (4 items): This scale reflects to what degree the school leader avoids responsibility, fails to make decisions, and is absent when needed. Examples of items are "The head of school most of the time is absent from the school when needed" and "The head of school avoids making decisions in the school". Cronbach's alpha for this scale was .73 .

Teachers were asked to indicate to which extent they agreed with each statement using a five-point Likert scale ranging from 1 (Excellent) to 5 (very poor). All questionnaires were close ended questions.

\section{Control Variables: Teacher Characteristics}

Teacher characteristics measured in this study are gender, age, teaching qualification, location of the school the teacher works at, and the teacher's years of experience in teaching. Age was measured by means of five categories: below 30 years old, 30-39 years old, 40-49 years old, 50-59 years old, and 60 years or older. Regarding their teaching qualification teachers could indicate whether they hold a 'Diploma in education', 'Bachelor degree', 'Master degree' or 'Doctorate degree'. For the location of the school, teachers could indicate whether the school is located in a rural or urban area. Years of experience was an open question, to which teachers could respond by filling in the number of years an individual teacher had been working as a teacher.

\section{Design and Procedure}

A survey design approach was employed in this study. Before collecting data, a permission to meet with teachers was sought from the District Educational officer and the head of each secondary school. The consent was also sought from each participant before the questionnaires were distributed to them. Collection of the filled-in questionnaires was either on the spot or the next day morning.

\section{Data Analysis}

To determine to what extent teachers' job satisfaction in Tanzanian public secondary schools is related to transactional and transformational leadership styles, a 
multiple regression analysis was conducted. The first model consists of an estimation of the effect of teacher background characteristics on their job satisfaction. In the second model, transformational and transactional leadership styles are added to the model. Thus the effect of each of the styles in combination with other leadership styles, while controlled for teacher characteristics, is estimated. The third model contains all factors that proved to be significant at $p<.05$. The reason for constructing this final model is that, given the conceptual likeness of some of the predictors included in the second model, multicollinearity and possibly an under- or overestimation of regression coefficients for the included predictors might arise. Non-significant predictors were removed stepwise from the model, while predictors with the relatively highest $\mathrm{p}$-value were removed first.

\section{Results}

Table 1 presents means and standard deviations for the transformational and transactional leadership styles. The mean rating of leadership styles vary from 2.25 to 3.37 on a five-point scale. This indicates, on average, that teachers do not consider any of the leadership styles to be characteristic for public secondary schools in southern Tanzania. Leadership styles that best reflect the practice in Songea secondary schools are charismatic leadership $(\mathrm{m}=3.37)$ and individualized consideration $(\mathrm{m}=3.25)$. This means that teachers thought of their leaders as relatively able to inspire teachers at their school, and that leaders more or less act as a mentor by paying attention to teachers' needs in school. About $43 \%$ of the teachers agreed that their principal indeed is was able to communicate attractive visions for the school, and to inspire and motivate teachers in school to achieve these aims (charismatic leadership). However, only one third of all teachers $(33 \%)$ thought of their principal as being sensitive to their needs and mentoring their development. About two thirds was indifferent to the school head being a mentor for teachers in their school or even thinks that their head is far from acting as a mentor.

Table 1. Means and standard deviations for leadership styles and job satisfaction.

\begin{tabular}{|c|c|c|c|}
\hline scales & $\mathrm{n}$ & mean & $\begin{array}{c}\text { standard } \\
\text { deviation }\end{array}$ \\
\hline Charismatic leadership & 180 & 3.37 & .88 \\
\hline Individualized consideration & 180 & 3.25 & .90 \\
\hline Intellectual stimulation & 180 & 3.07 & .93 \\
\hline Contingent reward & 180 & 2.82 & .80 \\
\hline Active management by exception & 180 & 3.13 & .76 \\
\hline Passive management by exception & 180 & 2.49 & .90 \\
\hline Laissez-faire & 180 & 2.25 & .77 \\
\hline Job satisfaction & 180 & 3.28 & .49 \\
\hline
\end{tabular}

These relatively low percentages are even lower for other aspects of leadership. The study results indicated that Teachers on average thought neither positively nor negatively about the intellectual stimulation of the principal $(\mathrm{m}=3.07)$ and the principal's active management by exception $(\mathrm{m}=3.13)$. This indicates that principals stimulating teachers to be innovative and creative by questioning assumptions, and reframing problems, are not common good in Tanzanian public secondary schools. Moreover, in general, school heads only marginally monitor teachers' performances in school, and only partially take action to correct any mistakes made by teachers. Teachers in general do not recognize that their leaders make rewards on performance $(\mathrm{m}=2.82)$, act passively based on incidents $(\mathrm{m}=2.49)$ or show laissez-faire leadership $(\mathrm{m}=2.25)$. Less than $15 \%$ of the teachers perceived the leadership style of the head of the school as contingent reward, passive management by exception or laissez-faire. Table 1 further shows that the teachers on average were only moderately satisfied with their job $(\mathrm{m}=$ $3.28)$.

Table 2. Differences in leadership styles between schools

\begin{tabular}{|c|c|c|c|c|}
\hline scales & $\begin{array}{c}\text { Sum of } \\
\text { squares }\end{array}$ & d.f. & F-value & Significance \\
\hline Charismatic leadership & 29.406 & 9 & 5.041 & .00 \\
\hline $\begin{array}{c}\text { Individualized } \\
\text { consideration }\end{array}$ & 30.247 & 9 & 5.053 & .00 \\
\hline Intellectual stimulation & 13.654 & 9 & 1.845 & .06 \\
\hline Contingent reward & 22.861 & 9 & 4.715 & .00 \\
\hline $\begin{array}{c}\text { Active management by } \\
\text { exception }\end{array}$ & 19.368 & 9 & 4.308 & .00 \\
\hline $\begin{array}{c}\text { Passive management by } \\
\text { exception }\end{array}$ & 22.092 & 9 & 3.358 & .00 \\
\hline Laissez-faire & 7.846 & 9 & 1.432 & .18 \\
\hline
\end{tabular}

Analysis of variance was used to determine whether secondary schools differ in leadership style. Table 2 reveals that there were statistically significant differences in leadership styles across schools. The results revealed significant Differences between schools regarding charismatic leadership of the school head $(F=5.041$, d.f. $=9, p=.00)$, the degree to which the head of the school pays attention to teachers' needs for further development $(F=5.053$, d.f. $=9, p$ $=.00)$, the degree to which heads reward teachers' performance $(\mathrm{F}=4.715$, d.f. $=9, \mathrm{p}=.00)$, and active $(\mathrm{F}=$ 4.308 , d.f. $=9, p=.00)$ and passive management by exception $(\mathrm{F}=3.358$, d.f. $=9, \mathrm{p}=.00)$. With regard to the intellectual stimulation of teachers $(\mathrm{F}=1.845$, d.f. $=9, \mathrm{p}$ $=.06)$ and a laissez-faire leadership style $(\mathrm{F}=1.432$, d.f. $=9$, $\mathrm{p}=.18)$ no significant differences were found.

Table 3 presents correlations between the various aspects of leadership styles, and between leadership styles and teachers' job satisfaction. Nearly all tested relationships were found to be significant. It was found out from the data collected that A charismatic leadership style is closely related to school leaders paying attention to teachers' need for achievement and personal growth $(\mathrm{r}=.84)$.

Similarly, it was further revealed that charismatic leadership in Songea secondary schools was is also significantly related 
to stimulating teachers' innovative and creativity behaviors by questioning their assumptions, reframing problems, and approaching old situations in new ways $(\mathrm{r}=.64)$, and to setting rewards for teachers' performance $(r=.65)$. Charismatic leadership is less clear correlated to active management by exception, and negatively related to passive management by exception $(\mathrm{r}=-.46)$, and a laissez-faire leadership approach $(\mathrm{r}=-.47)$.

Similarly, the study results revealed further that individualised consideration by the school head is closely related to intellectual stimulation by the school leader ( $\mathrm{r}$ $=.68)$, and contingent rewards in school $(\mathrm{r}=.73)$, and less strongly to active management by exception $(\mathrm{r}=-.47, \mathrm{r}=.31$ and $\mathrm{r}=.36$ respectively). These scales, similar to charismatic leadership, are negatively related to passive management by exception ( $\mathrm{r}=-.29$ to -.40$)$, and to a laissez-faire leadership approach $(\mathrm{r}=-.23$ to -.42$)$. Passive management by exception and a laissez-faire leadership style, in turn are positively related to each other $(\mathrm{r}=.58)$.

More importantly, it was found out in this study that Teachers' job satisfaction scale correlated positively with charismatic leadership $(\mathrm{r}=.74)$, individualised consideration of the school head $(\mathrm{r}=68)$, intellectual stimulation of teachers by the school leader $(r=.46)$, school leaders using contingent rewards $(\mathrm{r}=.54)$, and active management by exception $(\mathrm{r}=.37)(\mathrm{p}<.001)$. In addition to that, job satisfaction correlated negatively with leaders using passive management by exception $(\mathrm{r}=-.51, \mathrm{p}<.001)$, and school heads employing a laissez- faire style $(\mathrm{r}=-.40, \mathrm{p}<.001)$. This indicates that school heads who are not concerned with the needs of teachers, and not involved in the educational processes, only reacting to disruptions in school, lead to less satisfied teachers.

Table 3. Correlations between leadership styles and job satisfaction.

\begin{tabular}{|c|c|c|c|c|c|c|c|}
\hline & $\begin{array}{c}\text { Charismatic } \\
\text { leadership }\end{array}$ & Laissez-faire & Passive & $\begin{array}{c}\text { management } \\
\text { by exception }\end{array}$ & Active & $\begin{array}{c}\text { management } \\
\text { by exception }\end{array}$ & $\begin{array}{c}\text { Contingent } \\
\text { rewa }\end{array}$ \\
\hline $\begin{array}{c}\text { Individualized } \\
\text { consideration }\end{array}$ & $.84^{*}$ & & & & & & \\
\hline $\begin{array}{c}\text { Intellectual } \\
\text { stimulation }\end{array}$ & $.64^{*}$ & $.68 *$ & & & & & \\
\hline Contingent reward & $.65^{*}$ & $.73^{*}$ & .60 & & & & \\
\hline $\begin{array}{c}\text { Active management } \\
\text { by exception }\end{array}$ & $.50^{*}$ & $.47^{*}$ & .31 & .36 & & & \\
\hline $\begin{array}{c}\text { Passive management } \\
\text { by exception }\end{array}$ & $-.46^{*}$ & $-.40^{*}$ & -.33 & -.29 & -.07 & & \\
\hline Laissez-faire & $-.47^{*}$ & $-.42^{*}$ & -.34 & -.23 & -.07 & $.58 *$ & \\
\hline Job satisfaction & $.73^{*}$ & $.67 *$ & .46 & .54 & $.36 *$ & $-.51 *$ & $-.40 *$ \\
\hline
\end{tabular}

$* p<.001$.

Table 4. Effect of teacher background factors and leadership styles on predicting job satisfaction.

\begin{tabular}{|c|c|c|c|c|c|c|c|c|c|}
\hline & \multicolumn{3}{|c|}{ Model 1} & \multicolumn{3}{|c|}{ Model 2} & \multicolumn{3}{|c|}{ Model 3} \\
\hline & \multicolumn{3}{|c|}{ Standard error } & \multicolumn{3}{|c|}{ Standard error } & \multicolumn{3}{|c|}{ Standard error } \\
\hline & B & & $\mathrm{p}$ & B & & $\mathrm{p}$ & B & & $\mathrm{p}$ \\
\hline Constant & 3.10 & $(.22)$ & .00 & 2.16 & $(.23)$ & .00 & 2.26 & (.14) & .00 \\
\hline Gender (males) & -.08 & $(.07)$ & .23 & -.11 & $(.05)$ & .02 & -.11 & $(.04)$ & .02 \\
\hline Age & -.01 & $(.06)$ & .82 & .00 & $(.04)$ & .98 & & & \\
\hline School location & .15 & $(.09)$ & .10 & .06 & $(.06)$ & .31 & & & \\
\hline $\begin{array}{c}\text { Years of experience in } \\
\text { teaching }\end{array}$ & .01 & $(.01)$ & .13 & .01 & $(.01)$ & .36 & & & \\
\hline Diploma in Education & ref & ref & ref & ref & ref & ref & & & \\
\hline Bachelor degree & .04 & $(.08)$ & .60 & .02 & $(.05)$ & .64 & & & \\
\hline Master degree & -.55 & $(.15)$ & .00 & -.45 & $(.10)$ & .00 & -.47 & (.09) & .00 \\
\hline Charismatic leadership & & & & .28 & $(.05)$ & .00 & .27 & $(.05)$ & .00 \\
\hline $\begin{array}{c}\text { Individualized } \\
\text { consideration }\end{array}$ & & & & .11 & $(.05)$ & .05 & .12 & $(.05)$ & .01 \\
\hline Intellectual stimulation & & & & -.03 & $(.03)$ & .45 & & & \\
\hline Contingent reward & & & & .03 & $(.04)$ & .45 & & & \\
\hline $\begin{array}{l}\text { Active management by } \\
\text { exception }\end{array}$ & & & & .01 & $(.04)$ & .90 & & & \\
\hline $\begin{array}{l}\text { Passive management by } \\
\text { exception }\end{array}$ & & & & -.08 & $(.03)$ & .01 & -.08 & $(.03)$ & .01 \\
\hline Laissez-faire & & & & .03 & $(.04)$ & .47 & & & \\
\hline
\end{tabular}


To examine whether leadership styles are related to teachers' job satisfaction, while controlling for teacher characteristics, a stepwise regression analysis was performed (Table 4). In Model 1, teacher characteristics such as age, gender, teaching qualification, location of school and years of experience are added to the regression model. Model 1 revealed that teachers who hold a Master degree are less satisfied with their job than teachers with a diploma in education $(\mathrm{B}=-.55, \mathrm{p}<.001)$. Moreover, teachers with a Master degree also are less satisfied in their job than teachers with a Bachelor degree. These effects for teachers' qualification remain even after the style of leadership is added to the model (Model 2 and 3). Furthermore, male teachers appear to be less satisfied with their job than females $(\mathrm{B}=-.11, \mathrm{p}<.05)$. This difference between male and female teachers becomes significant after the transformational and transactional leadership styles are included in the model. This is caused by the fact that male teachers relatively more often work in schools with charismatic school heads who recognize the needs of their teachers, while female teachers relatively more often work in schools in which the school heads are hardly aware of the problems in school until warned by others, and who fail to act upon problems until these become urgent.

Charismatic leadership has a significant positive effect on teachers' job satisfaction $(\mathrm{B}=.27, \mathrm{p}<.001)$. As the head of the school works more closely with teachers, teachers are likely to be more satisfied with their job. Moreover, individualized consideration positively predicts teachers' job satisfaction $(\mathrm{B}=.12, \mathrm{p}<.05)$. This means that teachers who are satisfied with their job more often perceive their head of the school as acting as a mentor for them, and paying attention to their professional well-being. Meanwhile, passive management by exception had a significant negative relation to teachers' job satisfaction $(B=-.08, p<.05)$. The more the head of the school fails to take account the concerns of teachers in school and the problems that arise, the less teachers appear to be satisfied with their job.

For Model 3, R2 = ..66 which indicates that gender and teachers' qualification together with a charismatic leadership style, individualized consideration and passive management by exception explain 66 per cent of teachers' job satisfaction. The explained variance is very high and indicates that leadership style indeed appears to be an important predictor for the job satisfaction of teachers in southern Tanzania.

\section{Conclusions and Discussion}

This study explored the relationship between leadership styles applied by school heads and teachers' job satisfaction within Tanzanian public secondary schools. The results of the study show that both transformational and transactional leadership styles are used by principals in secondary schools. The findings revealed that transformational leadership styles, like charismatic leadership, individualized consideration and intellectual stimulation, as well as active management by exception - as a transactional leadership style - were relatively most used by heads of the Songea schools. However, in absolute terms, none of these leadership styles was very prominent according to teachers in their schools. This even more pertains to leaders using contingent rewards for teachers, showing passive management by exception or laissez-faire leadership the study reveals that the dimensions of transformational leadership appear more appropriate to characterize leadership in Songea secondary schools than dimensions of transactional leadership. Furthermore, it points out that substantial differences exist between schools regarding most of the discerned leadership styles. This indicates that teachers, at least to some extent, are consistent in how they perceive the leadership style of their school head.

The first research question concerned the relationship between leadership styles and teachers' job satisfaction. The transformational as well as part of the transactional leadership styles are related to job satisfaction, but they differ in magnitude and sign. Teachers' job satisfaction is positively related to charismatic leadership, individualized consideration, intellectual stimulation, contingent reward and active management by exception. A negative relationship was found in the area of passive management by exception and laissez-faire leadership. This finding is only partly in line with previous studies. Although all studies reveal effects for transformational leadership styles on teachers' job satisfaction [9] [18] [35], the outcomes for transactional leadership styles are less clear. [9] found a small negative effect of a composite scale for transactional leadership on teachers' job satisfaction. [35] in turn reported a positive effect for contingent reward leadership and passive management by exception, and no effect for active management by exception and a laissez-faire leadership approach on teachers' job satisfaction. In this study, a 'gross' negative relationship was found for passive management by exception and laissez-faire leadership. As these two transactional styles are negatively related to the other two, this suggests that a more directive role of the principal is distinct from a more passive style. For that reason, the transactional leadership scales sometimes are divided into 'positive' transactional leadership and passive or avoidant leadership [25]. This implies that transformational leadership styles may be present next to transactional leadership styles in the behavior of principals. This finding is in line with earlier findings that the two styles are not opposites of each other, but rather should be considered as on the same continuum see [9] [30] [35].

Job satisfaction proved not only to be dependent on leadership styles, but also on teacher characteristics. The study reveals that next to charismatic leadership, individualized consideration, and passive management by exception, the educational qualification and gender of teachers had an influence on teachers' job satisfaction. The importance of individual teacher characteristics is also reported in other studies on teachers' job satisfaction [8] [35]. The results of this study indicate that school teachers with a 
lower level of qualification (Diploma in education or a Bachelor degree) seem to be more satisfied with their job than more qualified teachers (a Master degree). This findings is in accordance with findings of [1] as well as [35] who found that there was a significant different between graduate and non-graduate teachers in job satisfaction. This finding might be explained by the fact that less qualified teachers might be more satisfied with their job because they are less likely to find another job. Teachers with a Master degree might think they have a job that is not appropriate for their level of education.

Similarly, male teachers appear to be less satisfied with being a teacher than female teachers. Previous studies indicate mixed evidence regarding gender even though, in education, several studies show that females tend to be more satisfied with their jobs than males [9] [35] [35] [33]. In addition, male teachers in Tanzania regularly choose this occupation as a last resort because of their inability to get a job that would better fit their academic credentials and qualifications. Under these circumstances, Tanzanian male teachers may feel frustrated and express greater dissatisfaction with their job. Support for the findings regarding the greater satisfaction of female teachers as compared to their male counterparts was also found in a study about the inner world of Israel secondary school teachers [28]. Assessment of additional private school and school site variables in relation to the study variables is recommended for future study to deepen our understand about leadership styles and teachers' job satisfaction in Tanzania and in comparison with other countries.

\section{REFERENCES}

[1] Abdullah, M. M., Uli, J., \& Parasuraman, B. (2009). Job satisfaction among secondary school teachers. Jurnal Kemanusiaan, 13, 11-18.

[2] Anderson, L. W. (2004). Increasing Teacher Effectiveness (2nd ed.). Paris: UNESCO, IIEP.

[3] Avolio, B. J., Bass, B. M., \& Jung, D. J. (1999). Re-examining the components of transformational and transactional leadership using the Multifactor Leadership Questionnaire. Journal of Occupational and Organisational Psychology, 72(4), 441-462.

[4] Bass, B. M. (1985). Leadership and performance beyond expectations. New York: The Free Press.

[5] Bass, B. M. (1997). Does the transactional-transformational leadership paradigm transcend organizational and national boundaries? American Psychologist, 52(2), 130-139.

[6] Bass, B. M. (1999a). Current developments in transformational leadership: Research and applications. The Psychologist Manager Journal, 3(1), 5-21.

[7] Bass, B. M. (1999b). Two Decades of Research and Development in Transformational leadership, European Journal of Work and Organizational Psychology, 8(1), 9-32.
[8] Bass, B. M., Avolio, B. J., Jung, D. I., \& Berson, Y. (2003). Predicting unit performance by assessing transformational and transactional leadership. Journal of Applied Psychology, 8(2), 207-218.

[9] Bass, B.M. \& Avolio, B.J. (1994). Transformation leadership and organizational culture. International Journal of Public Administration, 17, 541-555.

[10] Bogler, R. (2001). The influence of leadership style on teacher job satisfaction. Educational Administration Quarterly, 37(5), 662-683.

[11] Bolin, F. (2007). A Study of Teacher Job Satisfaction and Factors that Influence it. Chinese Education and Society, 40(5), 47-64.

[12] Burns, J. M. (1978). Leadership. New York: Harper \& Row.

[13] Cerit, Y. (2009). The Effects of Servant Leader ship Behaviours of School Principals on Teachers' Job Satisfaction. Educational Management Administration \& Leadership, 37(5), 600-623.

[14] Dinham, S., \& Scott, C. (2000). A three domain model of teacher and school executive career satisfaction. Journal of Educational Administration, 36(4), 362-378.

[15] Eagly, A., Johannesen-Schmidt, M., \& Vn Engen, M. (2003). Transformational, transactional, and laissez-faire leadership styles: A meta-analysis comparing women and men. Psychological Bulletin, 124(4), 569-591.

[16] Evans, V., \& Johnson, D.J. (1990). Teachers' job-related Stress. Journal of Instructional Psychology, 17(1), 11-18

[17] Geijsel, F., Sleegers, P., \& Van den Berg, R. (1999). Transformational leadership and the implementation of large-scale innovation programs. Journal of Educational Administration, 37(4), 309-328.

[18] Griffith, J. (2004). Relation of principal transformational leadership to school staff job satisfaction, staff turnover, and school performance. Journal of Educational Administration, 42(3), 333-356.

[19] Hackman, M.Z., \& Johnson, C.E. (2000). Leadership: A communication perspective (3rd ed.) Prospect Heights,IL:Waveland

[20] Hakielimu (2009). Government promises in Tanzania.Working paper,January, 2009. Dar es Salaam.

[21] Hartog, D., Van Muijen, J., \& Koopman, P. (1997). Transactional versus transformational leadership. An analysis of the MLQ. Journal of Occupational and Organizational Psychology, 70, 19-34.

[22] Hetland, H., \& Sandal, G. (2003).Transformational leadership in Norway: Outcomes and personality correlates. European Journal of Work and Organizational Psychology, 12(2), 147-170.

[23] Huang, M., Cheng, B., \& Chou, L. (2005). Fitting in organizational values: The mediating role of person-organization fit between CEO charismatic leadership and employee outcomes.International Journal of Manpower, 26(1). 35-49.

[24] Hulpia, H., Devos, G., \& Rosseel, Y. (2009). The relationship between the perception of distributed leadership in secondary schools and teachers' and teachers' job satisfaction and 
organizational commitment. School Effectiveness and School Improvement, 20(3), 291-317.

[25] Ibrahim, A. S., \& Al-Taneiji, S. (2013). Principal leadership style, school performance, and principal effectiveness in Dubai schools. International Journal of Research Studies in Education, 2(1), 41-54.

[26] Judge, T. A., \& Piccolo, R. F. (2004). Transformational and Transactional Leadership: A Meta-Analytic Test of Their Relative Validity. Journal of Applied Psychology, 89(5), $755-768$.

[27] Judge,T.A., Woolf, E.F., Hurst,C., \& Livingston, B.(2006). Charismatic and Transformational Leadership: A review and an Agenda for future research. Journal of organisation psychologie, 4, 203-214

[28] Kremer-Hayon, L., \& Goldstein, Z. (1990). The inner world of Israeli secondary school teachers: Work centrality, job satisfaction and stress. Comparative Education, 26(2/3), 285-298.

[29] Laub, J. A. (1999). Assessing the Servant Organization: Development of the Servant Organizational Leadership Assessment (SOLA) Instrument, Dissertation Abstracts International 60(2): 9921922.

[30] Leithwood, K., \& Jantzi, D. (2005). A Review of Transformational School Leadership Research 1996-2005. Leadership and Policy in Schools, 4(3), 177-199.

[31] Leithwood, K., Jantzi, D., \& Steinbach, R. (1999). Changing Leadership for Changing Times. London: Open University Press.

[32] Leithwood, K., Tomlinson, D., \& Genge, M. (1996). Transformational school leadership. In K. Leithwood (Ed.), International Handbook of Educational Leadership and Administration (pp. 785-840). Dordrecht: Kluwer Academic Publishers.

[33] Menon, M. E., \& Athanasoula-Reppa, A. (2011). Job satisfaction among secondary teachers: the role of gender and experience. School Leadership and Management, 31(5), 435-450.

[34] Menon, M. E., Papanastasiou, E., \& Zembylas, M. (2008). Examining the relationship of job satisfaction to teacher and organisational variables: Evidence from Cyprus. International Studies in Educational Administration, 36(3), 75-87.

[35] Nguni, S., Sleegers, P., \& Denessen, E. (2006). Transformational and transactional leadership effects on teachers' job satisfaction, organisational commitment, and organisational citizenship behaviour in primary schools: The Tanzanian case. School Effectiveness and School Improvement, 17(2), 145-177.
[36] Northouse, P. (2006). Leadership: Theory and practice Sage: Thousand Oaks, CA.

[37] Owens, R. G. (1991). Organisational behavior in education. Boston: Allyn \& Bacon.

[38] Perrachione, B. A., Petersen, G. J., \& Rosser, V. J. (2008). Why Do They Stay? Elementary teachers' perceptions of job satisfaction and retention. The Professional Education, 32(2), $1-17$.

[39] Rice, E.M., \& Schneider, G.T. (1994) A decade of teacher empowerment: An empirical analysis of teacher involvement in decision making, 1980-1991. Journal of Educational Administration, 32(1), 43-58.

[40] Rossmiller, R. A. (1992). The secondary school principal and teachers' quality of work life. Educational Management and Administration, 20(3), 132-146.

[41] Schulz, I.L \& Teddlie, C. (1986). The relationship between Teachers' Job satisfaction and their perception of principals' use of power and School effectiveness, Education, 109 (4), 461-68)

[42] Shamir, B. (1991). Meaning, self and motivation in organizations. Organizational Studies, 12(3), 405-424.

[43] Silins, H. C. (1994). The relationship between transformational and transactional leadership and school improvement outcomes. School Effectiveness and School Improvement, 5, 272-298.

[44] Silins, H., \& Mulford, B. (2002). Leadership and school results. In K. Leithwood \& P. Hallinger (Eds.), Second international handbook on educational leadership and administration (pp. 561-612). Dordrecht: Kluwer Academic Press.

[45] Smith, J. M. (2000). Analysis of the relationship between principal leadership style and teacher job satisfaction. Unpublished doctoral dissertation, The University of North Carolina at Charlotte, North Carolina.

[46] Van Eeden, R., Cilliers, F., \& Van Deventer, V. (2008). Leadership styles and associated personality traits: Support for the conceptualization of transactional and transformational leadership. South Africa Journal of psychology, 38(2), 253-267.

[47] Wedgwood, R.,(2007). Education and poverty reduction in Tanzania. International Journal of Education Development 27 383-396

[48] World Bank. (2010). Tanzania - Second Secondary Education Development Program Project. Washington, DC: World Bank.

[49] Yukl, G. (1998). Leadership in organizations (2nd ed.). Englewood Cliffs, NJ: Prentice Hall. 